\title{
Temporal and Spatial Variation in Susceptibility of Helicoverpa armigera (Hübner) Populations to Bollgard II BT Cotton in Tamil Nadu, India
}

\author{
S.A. Jayaprakash*, S. Mohan and M. Kannan \\ Department of Agricultural Entomology \\ Tamil Nadu Agricultural University \\ Coimbatore, Tamil Nadu, India
}

\begin{abstract}
The baseline susceptibility of Helicoverpa armigera (Hübner) from major cotton growing areas across Tamil Nadu, India was carried out with RCH 2 (Bollgard II) Bt cotton. Across the populations, Kovilpatti, Theni and Madurai populations were highly susceptible to leaves, squares and bolls of 60, 90, 120 and 150-day-old plants. The lowest mortality was observed in the populations of Attur and Coimbatore. Temporal and spatial variations of toxicity were observed in Bollgard II Bt cotton. The toxicity was higher at 60day-old plant parts, followed by 90, 120 and 150-day-old. Similarly, the leaves expressed higher toxicity than squares and bolls. Higher toxicity was recorded in detached fresh plant parts bioassayed over the diet incorporation bioassay.
\end{abstract}

Keywords: Baseline susceptibility, Bollgard II Bt cotton, Helicoverpa armigera

\section{INTRODUCTION}

Cotton is a very important fibre crop in India; farmers loose the cotton yield due to various insect pests at vegetative and reproductive stages of the crop. Among the insect species, the American bollworm, $H$. armigera, is the most serious pest, which causes about US \$1 billion worth of damage to agricultural crops in India (Gujar et al., 2000). H. armigera has acquired resistance to almost all the insecticides available in the market. Transgenic cotton, expressing the $\delta$-endotoxin gene from the bacterium Bacillus thuringiensis $(B t)$ is a promising technology to manage cotton bollworms (Naranjo and Vicente, 2008). Bt cotton has been the first genetically modified crop introduced to India during 2002 against bollworms. The first generation Bollgard cultivars (BG I) produces Cry1 Ac toxin to control H. armigera (Kranthi et al., 2009). During 2005 second generation Bollgard II (BG II) cultivars were introduced which contains, two Bt toxins, Cry $1 \mathrm{Ac}$ and Cry $2 \mathrm{Ab}$, and offer an improved pest management compared to Bollgard cultivars (Vitale et al., 2008). Baseline susceptibility of H. armigera to Cry 1Ac toxin in India is known (Gujar et al., 2000 \& Jalali et al., 2004) but there are no data on the extent of variability in $H$. armigera susceptibility to BG II cultivars in Tamil Nadu. Hence, the current study focused on the assessment of baseline susceptibility of cotton bollworm, H. armigera to the BG II Bt cotton cultivars in Tamil Nadu.

* Corresponding author: entojp@gmail.com 


\section{MATERIALS AND METHODS}

\section{Sampling Regions and Maintenance of $\boldsymbol{H}$. armigera Populations}

The study was conducted during 2010-2011 at Department of Agricultural Entomology, Tamil Nadu Agricultural University, Coimbatore, India. The H. armigera larvae were mostly collected as late instar larvae (III instar and above) in cotton fields during cropping season of 2009-2010 from major cotton growing regions of Tamil Nadu viz., Coimbatore, Attur, Madurai, Kovilpatti and Theni. The larvae collected from each location were reared separately till pupation on a semi synthetic diet (Patel et al., 1968). Adults, emerging from the pupae, were given 10 per cent honey solution throughout their egg-laying period. About 10 pairs of adults were kept in each jar. The eggs laid on muslin cloth were kept in a separate jar at $27{ }^{\circ} \mathrm{C}$ moistened with water. Upon hatching the neonate larvae were considered as F1 generation. The neonates belonging to different generations were used for this study.

\section{Bioassay with Detached Plant Parts}

Bioassays were conducted using detached plant parts of 60, 90, 120 and 150-day-old BG II $B t$ cotton and non-Bt cotton ( $\mathrm{RCH} 2$ ) viz., fully opened fourth leaf, squares and bolls from two to three nodes below the terminal end. The detached leaves were cut into small pieces and placed on moist filter paper in Petri plates. Similarly, square and bolls were kept in plastic polypots. The test materials were changed once in three days. Ten first instar larvae of different geographic population of $H$. armigera were released in each Petri plate and polypot. Each treatment was replicated three times and at least 30 larvae were used per experimental unit. Mortality of the larvae was recorded every 24 hours for seven days. The larvae were marked dead when they did not move when prodded. All the experiments were carried out in a room with photoperiod of 14: 10 (L: D) and average temperature of $27{ }^{\circ} \mathrm{C}$ with 60 per cent relative humidity.

\section{Diet Incorporation Bioassay}

For diet incorporation bioassay, the plant tissues of 60, 90, 120 and 150-day-old BG II $B t$ cotton and non-Bt cotton (RCH 2) viz., fully opened fourth leaf, squares and bolls from two to three nodes below the terminal end were collected from farmer fields and placed individually in zip-lock sample bags and were immediately frozen on dry ice. After samples were thoroughly frozen, either on dry ice $\left(-40{ }^{\circ} \mathrm{C}\right)$ or in ultra-low freezer $\left(-80{ }^{\circ} \mathrm{C}\right)$, the samples were completely lyophilized for duration of two days. When lyophilization was completed, samples were removed and individually grounded at room temperature using pestle and mortar; cotton lint, which was two fibrous to grind, was removed from mature boll samples. Grinding was completed when the dry powder would go through a 40 mesh sieve. Individual powder samples were stored in labeled screw-cap vials at $-20{ }^{\circ} \mathrm{C}$ (Greenplate, 1999).

For bioassay, $100 \mathrm{mg}$ of powder sample was diluted with $5.0 \mathrm{ml}$ of 0.2 per cent agar solution. Further dilutions of this 2 per cent (wt: vol) powder slurry stock were made in 0.2 per cent agar to create samples for application to insect diet. The samples were transferred at the rate of $500 \mu \mathrm{l}$ of sample in 0.2 per cent agar to surface of $5 \mathrm{ml}$ chickpea based diet in the wells of diet tray ( 32 well larval rearing trays). The diet tray was left open under the hood and the samples were allowed to surface dry. Care was taken not to over dry the diet. Once the samples had dried, 30 first instar larvae were released in to each tray ( 32 well multi-cavity 
tray) and were sealed. Mortality of the larvae was recorded every 24 hours for seven days. The larvae were marked dead when they did not move when prodded (Navon, 2000). All the experiments were carried out in a room with photoperiod of 14: 10 (L: D) and average temperature of $27^{\circ} \mathrm{C}$ with 60 per cent relative humidity.

\section{Statistical Analysis}

One way analysis of variance was carried out in completely randomized design as described by Gomez and Gomez (1984). Square root transformation was done to determine the significance in the differences between the mean values of mortality.

\section{RESULTS AND DISCUSSION}

Geographic variations of the susceptibility of important insect pests have not been established for transgenic crops. But, few countries have established baseline susceptibility to respective Bt proteins (Jalali et al., 2004). Results of the present study revealed that all the populations were highly susceptible to all plant parts (leaves, squares and bolls) of different ages (60, 90, 120 and 150-day-old) of transgenic BG II Bt cotton (RCH 2) (Table 1 and 3) and least susceptible to non- $B t$ cotton (Table 2 and 4 ), respectively. The toxicity was highest on 60-day-old plant parts followed by 90,120 and 150-day-old. Across the populations, Kovilpatti, Theni and Madurai populations were highly susceptible to leaves, squares and bolls of 60, 90, 120 and 150-day-old plants, respectively. Lowest mortality was observed in the populations of Attur and Coimbatore.

\section{Baseline Susceptibility of $\boldsymbol{H}$. armigera in Detached Plant Part Bioassay Method}

The results of the study show the toxicity of different plant parts of BG II $B t$ cotton (RCH 2) to the H. armigera larvae collected from various places of Tamil Nadu. Population from Kovilpatti ( 80 to 100 per cent), Theni ( 76.7 to 96.7 per cent) and Madurai (76.7 to 93.3 per cent) had the highest mortality, whereas, populations from Attur (70 to 83.3 per cent) and Coimbatore (70 to 86.7 per cent) had the lowest mortality at different age of crop growth (Table 1). Bioassay results indicated that there was variability across the populations of $H$. armigera. Similar studies conducted in India showed geographic variations in susceptibility of insects to different $B t$ proteins. H. armigera collected from more than 15 locations across India also showed around 10 fold variations in the susceptibility (Gujar et al., 2000). 
Table 1. Mortality of $\boldsymbol{H}$. armigera larvae (detached plant part bioassay) in RCH 2 (Bollgard II) Bt cotton

\begin{tabular}{|c|c|c|c|c|c|c|c|c|}
\hline \multirow{2}{*}{$\begin{array}{l}\text { Crop age and } \\
\text { Plant parts }\end{array}$} & \multicolumn{5}{|c|}{ Location and mortality $(\%) \pm \mathrm{SE}$} & \multirow{2}{*}{ SEd } & \multirow{2}{*}{$\begin{array}{c}\text { CD } \\
(5 \%)\end{array}$} & \multirow{2}{*}{$\begin{array}{l}\text { CV } \\
\%\end{array}$} \\
\hline & Coimbatore & Attur & Madurai & Kovilpatti & Theni & & & \\
\hline \multicolumn{9}{|l|}{ Bt cotton- 60 day } \\
\hline Leaves & $86.67 \mathrm{~cd} \pm 2.17$ & $83.33 \mathrm{~d} \pm 2.08$ & $93.33 \mathrm{bc} \pm 2.33$ & $100.00 \mathrm{a} \pm 2.50$ & $96.67 \mathrm{ab} \pm 2.42$ & 3.7794 & 7.8836 & 8.09 \\
\hline Squares & $80.00 \mathrm{bc} \pm 2.00$ & $76.67 \mathrm{~d} \pm 1.92$ & $86.67 b \pm 2.17$ & $93.33 \mathrm{a} \pm 2.33$ & $93.33 \mathrm{a} \pm 2.33$ & 2.8117 & 5.865 & 6.59 \\
\hline \multicolumn{9}{|l|}{ Bt cotton- 90 day } \\
\hline Leaves & $83.33 \mathrm{c} \pm 2.08$ & $83.33 \mathrm{c} \pm 2.08$ & $86.67 \mathrm{bc} \pm 2.17$ & $96.67 \mathrm{a} \pm 2.42$ & $93.33 \mathrm{ab} \pm 2.33$ & 3.2385 & 6.7553 & 7.34 \\
\hline Squares & $80.00 \mathrm{~cd} \pm 2.00$ & $76.67 \mathrm{~d} \pm 1.92$ & $86.67 \mathrm{bc} \pm 2.17$ & $93.33 \mathrm{a} \pm 2.33$ & $90.00 \mathrm{ab} \pm 2.25$ & 2.6346 & 5.4956 & 6.24 \\
\hline Bolls & $76.67 \mathrm{c} \pm 1.92$ & $76.67 \mathrm{c} \pm 1.92$ & $83.33 b c \pm 2.08$ & $90.00 \mathrm{a} \pm 2.25$ & $86.67 \mathrm{ab} \pm 2.17$ & 2.2667 & 4.7282 & 5.55 \\
\hline \multicolumn{9}{|l|}{$\begin{array}{l}\text { Bt cotton-120 } \\
\text { day }\end{array}$} \\
\hline Leaves & $83.33 b c \pm 2.08$ & $76.67 \mathrm{c} \pm 1.92$ & $86.67 \mathrm{~b} \pm 2.17$ & $93.33 \mathrm{a} \pm 2.33$ & $90.00 \mathrm{ab} \pm 2.25$ & 2.6686 & 5.5666 & 6.27 \\
\hline Squares & $76.67 \mathrm{c} \pm 1.92$ & $76.67 \mathrm{c} \pm 1.92$ & $83.33 b c \pm 2.08$ & $90.00 \mathrm{a} \pm 2.25$ & $86.67 \mathrm{ab} \pm 2.17$ & 2.2667 & 4.7282 & 5.55 \\
\hline Bolls & $73.33 \mathrm{c} \pm 1.83$ & $70.00 \mathrm{c} \pm 1.75$ & $80.00 \mathrm{~b} \pm 2.00$ & $86.67 \mathrm{a} \pm 2.17$ & $83.33 \mathrm{ab} \pm 2.08$ & 1.9927 & 4.1567 & 5.11 \\
\hline \multicolumn{9}{|l|}{$\begin{array}{l}\text { Bt cotton-150 } \\
\text { day }\end{array}$} \\
\hline Leaves & $80.00 \mathrm{bc} \pm 1.83$ & $76.67 \mathrm{c} \pm 1.75$ & $83.33 \mathrm{ab} \pm 1.92$ & $86.67 \mathrm{a} \pm 2.08$ & $83.33 \mathrm{ab} \pm 2.00$ & 1.8422 & 3.8427 & 4.83 \\
\hline Squares & $73.33 \mathrm{~cd} \pm 1.83$ & $70.00 \mathrm{~d} \pm 1.75$ & $76.67 \mathrm{bc} \pm 1.83$ & $83.33 a \pm 2.00$ & $80.00 \mathrm{ab} \pm 1.92$ & 1.7269 & 3.6023 & 4.64 \\
\hline Bolls & $70.00 \mathrm{~b} \pm 1.67$ & $70.00 \mathrm{~b} \pm 1.58$ & $76.67 \mathrm{a} \pm 1.75$ & $80.00 \mathrm{a} \pm 1.92$ & $76.67 \mathrm{a} \pm 1.83$ & 1.552 & 3.2389 & 4.38 \\
\hline
\end{tabular}

The values are means of 30 observations; means followed by different letters within a column indicate significant differences $(\mathrm{P}=0.05$ : LSD)

SE - Standard Error

The study obviously showed the temporal variations in the susceptibility of $H$. armigera larvae to BG II Bt cotton (RCH 2). The highest mortality was observed at 60-day-old Bt cotton plant parts followed by 90,120 and 150-day-old. This results are consistent with the finding of Fitt et al. (1994); Fitt (1998); Olsen et al. (1998); Adamczyk et al. (2001); Srinivasan and Uthamasamy (2006); Kannan and Uthamasamy (2007). Olsen et al. (2005) suggested that the developmental decline in expression and toxicity of Cry $1 \mathrm{Ac}$ gene was associated with reduced CrylAc mRNA transcript and toxin levels in post squaring cotton. The reduction in Cry1 Ac mRNA transcript was most likely due to a failure of the ${ }^{35} \mathrm{~S}$ promoter in post squaring cotton. In addition, changes in plant physiology, associated with the maturation of the cotton plant were observed to contribute changes in the efficacy on Bt cotton.

The results of the experiment also revealed that expression of toxicity vary with plant parts; leaves expressed higher toxicity followed by squares and bolls. This result is in conformity with Mohan and Manjunath (2002) and Kranthi et al. (2005), who reported that the concentrations of CrylAc in reproductive tissue, in Indian hybrids were relatively lower. Table 2 of the present study revealed that $H$. armigera larvae collected from different locations were least susceptible to non-Bt cotton. 
Table 2. Mortality of $\boldsymbol{H}$. armigera larvae (detached plant part bioassay) in RCH 2 Non-Bt cotton

\begin{tabular}{|c|c|c|c|c|c|c|c|c|}
\hline \multirow{2}{*}{$\begin{array}{l}\text { Crop age and } \\
\text { Plant parts }\end{array}$} & \multicolumn{5}{|c|}{ Location and mortality $(\%) \pm \mathrm{SE}$} & \multirow{2}{*}{ SEd } & \multirow{2}{*}{$\begin{array}{c}\text { CD } \\
(5 \%)\end{array}$} & \multirow{2}{*}{$\begin{array}{l}\text { CV } \\
\%\end{array}$} \\
\hline & Coimbatore & Attur & Madurai & Kovilpatti & Theni & & & \\
\hline \multicolumn{9}{|c|}{$\begin{array}{l}\text { Non-Bt cotton-60 } \\
\text { day }\end{array}$} \\
\hline Leaves & $6.70 \mathrm{c} \pm 0.17$ & $3.33 \mathrm{~d} \pm 0.08$ & $10.00 \mathrm{~b} \pm 0.25$ & $13.00 \mathrm{a} \pm 0.33$ & $10.00 \mathrm{~b} \pm 0.25$ & 0.3168 & 0.6608 & 3.03 \\
\hline Squares & $3.33 c \pm 0.083$ & $3.33 \mathrm{c} \pm 0.083$ & $6.67 b \pm 0.167$ & $10.00 \mathrm{a} \pm 0.25$ & $6.67 \mathrm{~b} \pm 0.167$ & 0.2598 & 0.5418 & 2.99 \\
\hline \multicolumn{9}{|c|}{$\begin{array}{l}\text { Non-Bt cotton-90 } \\
\text { day }\end{array}$} \\
\hline Leaves & $3.33 \mathrm{c} \pm 0.08$ & $3.33 \mathrm{c} \pm 0.08$ & $6.67 b \pm 0.17$ & $10.00 \mathrm{a} \pm 0.25$ & $10.00 \mathrm{a} \pm 0.25$ & 0.2755 & 0.5747 & 3.02 \\
\hline Squares & $3.33 b \pm 0.08$ & $3.33 b \pm 0.08$ & $6.67 \mathrm{a} \pm 0.17$ & $6.67 \mathrm{a} \pm 0.17$ & $6.67 \mathrm{a} \pm 0.17$ & 0.2431 & 0.5072 & 2.95 \\
\hline Bolls & $3.33 b \pm 0.08$ & $3.33 b \pm 0.08$ & $3.33 b \pm 0.08$ & $6.67 \mathrm{a} \pm 0.17$ & $3.33 b \pm 0.08$ & 0.2091 & 0.4361 & 2.94 \\
\hline \multicolumn{9}{|c|}{$\begin{array}{l}\text { Non- } B t \text { cotton- } \\
120 \text { day }\end{array}$} \\
\hline Leaves & $3.33 b \pm 0.08$ & $6.67 \mathrm{a} \pm 0.17$ & $3.33 b \pm 0.08$ & $6.67 \mathrm{a} \pm 0.17$ & $6.67 \mathrm{a} \pm 0.17$ & 0.2433 & 0.5075 & 2.95 \\
\hline Squares & $3.33 b \pm 0.08$ & $3.33 b \pm 0.08$ & $3.33 b \pm 0.08$ & $6.67 \mathrm{a} \pm 0.17$ & $3.33 b \pm 0.08$ & 0.2093 & 0.4365 & 2.94 \\
\hline Bolls & $0.00 \mathrm{~b} \pm 0.00$ & $0.00 \mathrm{~b} \pm 0.00$ & $0.00 \mathrm{~b} \pm 0.00$ & $3.33 \mathrm{a} \pm 0.08$ & $3.33 \mathrm{a} \pm 0.08$ & 0.1203 & 0.251 & 4.25 \\
\hline \multicolumn{9}{|c|}{$\begin{array}{l}\text { Non-Bt cotton- } \\
150 \text { day }\end{array}$} \\
\hline Leaves & $3.33 a \pm 0.00$ & $3.33 \mathrm{a} \pm 0.00$ & $3.33 \mathrm{a} \pm 0.08$ & $3.33 \mathrm{a} \pm 0.08$ & $0.00 \mathrm{~b} \pm 0.00$ & 0.1474 & 0.3075 & 3.61 \\
\hline Squares & $0.00 \mathrm{~b} \pm 0.00$ & $0.00 \mathrm{~b} \pm 0.00$ & $3.33 a \pm 0.08$ & $3.33 a \pm 0.08$ & $0.00 \mathrm{~b} \pm 0.00$ & 0.1203 & 0.251 & 4.25 \\
\hline Bolls & $0.00 \mathrm{~b} \pm 0.00$ & $0.00 \mathrm{~b} \pm 0.00$ & $0.00 \mathrm{~b} \pm 0.00$ & $3.33 a \pm 0.08$ & $0.00 \mathrm{~b} \pm 0.00$ & 0.0851 & 0.1775 & 5.38 \\
\hline
\end{tabular}

The values are means of 30 observations; means followed by different letters within a column indicate significant differences $(\mathrm{P}=0.05$ : LSD)

SE - Standard Error

\section{Baseline Susceptibility of $\boldsymbol{H}$. armigera in Diet Incorporation Bioassay Method}

The study reported that percentage mortality of $H$. armigera in (diet incorporation bioassay method) lyophilized plant parts of BG II Bt cotton ( $\mathrm{RCH} 2$ ) ranged from $63.33 \mathrm{~d} \pm 1.58$ to $93.33 \pm 2.33$ per cent (Table 3 ). Among the populations, lower susceptibility was noticed in Attur (63.3 to 83.3 per cent) and Coimbatore (66.7 to 83.3 per cent) population, whereas higher mortality was recorded in Kovilpatti ( 76.7 to 93.3 per cent), Theni ( 73.3 per cent 93.3 per cent) and Madurai (70 to 86.7 per cent) populations. Table 4 of the present study showed that $H$. armigera larvae collected from different locations were least susceptible to non- $B t$ cotton. 
Table 3. Mortality of $\boldsymbol{H}$. armigera larvae (diet incorporation bioassay) in RCH 2 (Bollgard II) Bt cotton

\begin{tabular}{|c|c|c|c|c|c|c|c|c|}
\hline \multirow{2}{*}{$\begin{array}{l}\text { Crop age and } \\
\text { Plant parts }\end{array}$} & \multicolumn{5}{|c|}{ Location and mortality $(\%) \pm \mathrm{SE}$} & \multirow{2}{*}{ SEd } & \multirow{2}{*}{$\begin{array}{c}\text { CD } \\
(5 \%)\end{array}$} & \multirow{2}{*}{$\begin{array}{c}\text { CV } \\
\%\end{array}$} \\
\hline & Coimbatore & Attur & Madurai & Kovilpatti & Theni & & & \\
\hline \multicolumn{9}{|c|}{$B t$ cotton- 60 day } \\
\hline Leaves & $83.33 b \pm 2.08$ & $83.33 b \pm 2.08$ & $86.67 b \pm 2.17$ & $93.33 \mathrm{a} \pm 2.3$ & $93.33 \mathrm{a} \pm 2.33$ & 2.8978 & 6.0448 & 6.65 \\
\hline Squares & $80.00 \mathrm{~b} \pm 2.00$ & $76.67 \mathrm{~b} \pm 1.92$ & $83.33 b \pm 2.08$ & $90.00 \mathrm{a} \pm 2.25$ & $90.00 \mathrm{a} \pm 2.25$ & 2.3898 & 4.9849 & 5.76 \\
\hline \multicolumn{9}{|c|}{ Bt cotton- 90 day } \\
\hline Leaves & $83.33 \mathrm{bc} \pm 2.08$ & $76.67 \mathrm{c} \pm 1.92$ & $83.33 b c \pm 2.08$ & $90.00 \mathrm{a} \pm 2.25$ & $86.67 \mathrm{ab} \pm 2.17$ & 2.3344 & 4.8695 & 5.64 \\
\hline Squares & $76.67 b \pm 1.92$ & $76.67 \mathrm{~b} \pm 1.92$ & $83.33 \mathrm{a} \pm 2.08$ & $86.67 \mathrm{a} \pm 2.17$ & $83.33 \mathrm{a} \pm 2.08$ & 2.1049 & 4.3907 & 5.25 \\
\hline Bolls & $73.33 \mathrm{~b} \pm 1.83$ & $70.00 \mathrm{~b} \pm 1.75$ & $80.00 \mathrm{a} \pm 2.00$ & $83.33 a \pm 2.08$ & $80.00 \mathrm{a} \pm 2.00$ & 1.8775 & 3.9163 & 4.89 \\
\hline \multicolumn{9}{|l|}{$\begin{array}{l}\text { Bt cotton- } 120 \\
\text { day }\end{array}$} \\
\hline Leaves & $76.67 \mathrm{c} \pm 1.92$ & $76.67 \mathrm{c} \pm 1.92$ & $80.00 \mathrm{bc} \pm 2.00$ & $86.6 \mathrm{a} \pm 2.17$ & $83.33 \mathrm{ab} \pm 2.08$ & 2.0616 & 4.3004 & 5.18 \\
\hline Squares & $73.33 \mathrm{bc} \pm 1.83$ & $70.00 \mathrm{c} \pm 1.75$ & $76.67 \mathrm{~b} \pm 1.92$ & $83.33 \mathrm{a} \pm 2.08$ & $76.67 \mathrm{~b} \pm 1.92$ & 1.8062 & 3.7677 & 4.77 \\
\hline Bolls & $70.00 \mathrm{bc} \pm 1.75$ & $66.67 \mathrm{c} \pm 1.67$ & $70.00 \mathrm{bc} \pm 1.75$ & $80.00 \mathrm{a} \pm 2.00$ & $73.33 b \pm 1.83$ & 1.6306 & 3.4014 & 4.5 \\
\hline \multicolumn{9}{|l|}{$\begin{array}{l}\text { Bt cotton-150 } \\
\text { day }\end{array}$} \\
\hline Leaves & $73.33 \mathrm{~cd} \pm 1.83$ & $70.00 \mathrm{~d} \pm 1.75$ & $76.67 \mathrm{c} \pm 1.92$ & $83.33 a \pm 2.08$ & $80.00 \mathrm{ab} \pm 2.00$ & 1.8422 & 3.8427 & 4.83 \\
\hline Squares & $73.33 b c \pm 1.83$ & $70.00 c \pm 1.75$ & $73.33 b c \pm 1.83$ & $80.00 \mathrm{a} \pm 2.00$ & $76.67 \mathrm{ab} \pm 1.92$ & 1.7269 & 3.6023 & 4.64 \\
\hline Bolls & $66.67 \mathrm{~cd} \pm 1.67$ & $63.33 \mathrm{~d} \pm 1.58$ & $70.00 b c \pm 1.75$ & $76.67 \mathrm{a} \pm 1.92$ & $73.33 \mathrm{ab} \pm 1.83$ & 1.5527 & 3.2389 & 4.38 \\
\hline
\end{tabular}

The results of the present study indicate the variation in susceptibility of $H$. armigera to transgenic BG II Bt cotton ( $\mathrm{RCH} 2$ ) across Tamil Nadu both in detached plant parts and diet incorporation assays. The results are in agreement with findings of Kannan and Uthamasamy (2007). They revealed that Guntur and Raichur populations were least susceptible and Coimbatore, Dharwad, Warangal, Attur populations were moderate to most susceptible to $B t$ cotton ( $\mathrm{RCH} 2)$. The results of the present investigation are in contrast with the findings of Gujar et al. (2000, 2007), Kranthi et al. (2000, 2009), Fakrudin et al. (2003) and Jalali et al. (2004) in India. The mortality of $H$. armigera larvae were low on diet incorporated with lyophilized plant materials than detached plant parts of fresh materials. Similarly, Kannan and Uthamasamy (2007) also reported that diet incorporation bioassays detected a highly significant decline in the efficacy, than detached fresh plant parts bioassays against $H$. armigera. 
Table 4. Mortality of $\boldsymbol{H}$. armigera larvae (diet incorporation bioassay) in RCH 2 NonBt cotton

\begin{tabular}{|c|c|c|c|c|c|c|c|c|}
\hline \multirow{2}{*}{$\begin{array}{l}\text { Crop age and } \\
\text { Plant parts }\end{array}$} & \multicolumn{5}{|c|}{ Location and mortality $(\%) \pm \mathrm{SE}$} & \multirow{2}{*}{ SEd } & \multirow{2}{*}{$\begin{array}{c}\text { CD } \\
(5 \%)\end{array}$} & \multirow{2}{*}{$\mathrm{CV} \%$} \\
\hline & Coimbatore & Attur & Madurai & Kovilpatti & Theni & & & \\
\hline \multicolumn{9}{|l|}{$\begin{array}{l}\text { Non- } B t \text { cotton- } \\
60 \text { day }\end{array}$} \\
\hline Leaves & $3.33 c \pm 0.08$ & $3.33 \mathrm{c} \pm 0.08$ & $6.67 \mathrm{a} \pm 0.17$ & $6.67 \mathrm{a} \pm 0.17$ & $6.00 \mathrm{~b} \pm 0.15$ & 0.2401 & 0.5007 & 2.94 \\
\hline Squares & $3.33 b \pm 0.08$ & $3.33 b \pm 0.08$ & $3.33 b \pm 0.08$ & $6.67 \mathrm{a} \pm 0.17$ & $3.00 \mathrm{c} \pm 0.08$ & 0.2073 & 0.4325 & 2.94 \\
\hline \multicolumn{9}{|l|}{$\begin{array}{l}\text { Non-Bt cotton- } \\
90 \text { day }\end{array}$} \\
\hline Leaves & $0.00 \mathrm{c} \pm 0.00$ & $3.33 b \pm 0.08$ & $3.33 b \pm 0.08$ & $6.67 \mathrm{a} \pm 0.17$ & $6.67 \mathrm{a} \pm 0.17$ & 0.2104 & 0.439 & 3.27 \\
\hline Squares & $0.00 \mathrm{c} \pm 0.00$ & $0.00 \mathrm{c} \pm 0.00$ & $0.00 \mathrm{c} \pm 0.00$ & $6.67 \mathrm{a} \pm 0.17$ & $3.33 b \pm 0.08$ & 0.1488 & 0.3104 & 4.39 \\
\hline Bolls & $0.00 \mathrm{~b} \pm 0.00$ & $0.00 \mathrm{~b} \pm 0.00$ & $0.00 \mathrm{~b} \pm 0.00$ & $3.33 \mathrm{a} \pm 0.08$ & $0.00 \mathrm{~b} \pm 0.00$ & 0.0851 & 0.1775 & 5.38 \\
\hline \multicolumn{9}{|l|}{$\begin{array}{l}\text { Non-Bt cotton- } \\
120 \text { day }\end{array}$} \\
\hline Leaves & $0.00 \mathrm{~b} \pm 0.00$ & $0.00 \mathrm{~b} \pm 0.00$ & $3.33 \mathrm{a} \pm 0.08$ & $3.33 \mathrm{a} \pm 0.08$ & $3.33 a \pm 0.08$ & 0.1474 & 0.3075 & 3.61 \\
\hline Squares & $0.00 \mathrm{~b} \pm 0.00$ & $0.00 \mathrm{~b} \pm 0.00$ & $3.33 a \pm 0.08$ & $3.33 \mathrm{a} \pm 0.08$ & $3.33 a \pm 0.08$ & 0.1474 & 0.3075 & 3.61 \\
\hline Bolls & $0.00 \mathrm{~b} \pm 0.00$ & $0.00 \mathrm{~b} \pm 0.00$ & $0.00 \mathrm{~b} \pm 0.00$ & $3.33 a \pm 0.08$ & $0.00 \mathrm{~b} \pm 0.00$ & 0.0851 & 0.1775 & 5.38 \\
\hline \multicolumn{9}{|l|}{$\begin{array}{l}\text { Non-Bt cotton- } \\
150 \text { day }\end{array}$} \\
\hline Leaves & $0.00 \mathrm{~b} \pm 0.00$ & $0.00 \mathrm{~b} \pm 0.00$ & $3.33 a \pm 0.08$ & $3.33 a \pm 0.08$ & $3.33 a \pm 0.08$ & 0.1474 & 0.3075 & 3.61 \\
\hline Squares & $0.00 \mathrm{~b} \pm 0.00$ & $0.00 \mathrm{~b} \pm 0.00$ & $3.33 \mathrm{a} \pm 0.08$ & $3.33 a \pm 0.08$ & $0.00 \mathrm{~b} \pm 0.08$ & 0.1203 & 0.251 & 4.25 \\
\hline Bolls & $0.00 \mathrm{~b} \pm 0.00$ & $0.00 \mathrm{~b} \pm 0.00$ & $0.00 \mathrm{~b} \pm 0.00$ & $3.33 a \pm 0.08$ & $0.00 \mathrm{~b} \pm 0.00$ & 0.0851 & 0.1775 & 5.38 \\
\hline
\end{tabular}

\section{CONCLUSIONS}

The variations in the baseline susceptibility data is the indication of the development of resistance among the population of insects. In order to develop a effective pest management programmes and to develop a strategy to overcome resistant development for the effective control of insects, there is a need for continuous monitoring of temporal, spatial baseline susceptibility changes. The presence of variations in the susceptible populations of $H$. armigera also may lead to the development of resistance in the future. However, it depends on the presence of genetic inheritance of the resistance and selection pressure given to the target insect over period of time. Establishment of baseline information may provide the basis for rational resistance management strategies to retard the rate of development or resistance in cotton production. 


\section{ACKNOWLEDGEMENT}

We thank Department of Agricultural Entomology, Tamil Nadu Agricultural University, Coimbatore for providing basic infrastructural facilities to carry out the above work.

\section{REFERENCES}

Adamczyk, J.J.Jr., Hardee, D.D., Adams, L.C. and Sumerford, D.V. (2001). Correlating differences in larval survival and development of bollworms (Lepidoptera: Noctuidae) and fall armyworms (Lepidoptera: Noctuidae) to differential expression of CrylA(c) $\delta$ endotoxin in various plant parts among commercial cultivars of transgenic Bacillus thuringiensis cotton. J. Econ. Entomol. 94, 284-290.

Fakrudin, B., Prasad, P.R.B, Prakash, S.K., Reddy, H.B.K., Patil B.V., and Kuruvinashetti, M.S. (2003). Baseline resistance to Cry1 Ac toxin in cotton bollworm, Helicoverpa armigera (Hubner) in South India cotton ecosystem. Curr. Sci. 84, 1304-1307.

Fitt, G.P. (1998). Efficacy of Ingard $\mathbb{R}$ cotton - patterns and consequences. In: Proceedings, $9^{\text {th }}$ Australian Cotton Conference, 12-14 August 1998, Broadbeach, Queensland. Australian Cotton Growers Research Association, WeeWaa, NSW, Australia. pp. 233-245.

Fitt, G.P., Mares, C.L. and Llewellyn, D.J. (1994). Field evaluation and potential ecological impact of transgenic cottons (Gosssypium hirsutum). Aus. Bio. Sci.Tech. 4, 535-548.

Gomez, K.A. and Gomez, A.A. (1984). Statistical Procedures for Agricultural Research. Second edition. John Wiley \& sons, New York. p. 680.

Greenplate, J.T. (1999). Quantification of Bacillus thuringiensis insect control protein Cry1 Ac over time in Bollgard cotton fruit and terminals. J. Econ. Entomol. 92, 1377-1383.

Gujar, G.T., Kumari, A., Kalia, V. and Chandrashekar, K. (2000). Spatial and temporal variation in susceptibility of the American bollworm, Helicoverpa armigera (Hubner) to Bacillus thuringiensis var. kurstaki in India.

Curr. Sci. 78, 995-1001.

Gujar, G.T., Kalia, V., Kumari, A., Singh, B.P., Mittal, A., Nair, R. and Mohan, M. (2007). Helicoverpa armigera baseline susceptibility to Bacillus thuringiensis (Bt) Cry toxins and resistance management for Bt cotton in India. J. Invert. Pathol. 95, 214-219.

Jalali, S.K., Mohan, K.S., Singh, S.P., Manjunath, T.M. and Lalitha, Y. (2004). Baseline susceptibility of the old-world bollworm Helicoverpa armigera (Hübner) (Lepidoptera: Noctuidae) populations from India to Bacillus thuringiensis Cry1Ac Insecticidal Proteins. Crop Prot. 23, 53-59.

Kannan, M. and Uthamasamy, S. (2007). Baseline Susceptibility of the Cotton Bollworm, Helicoverpa armigera (Hübner) (Lepidoptera: Noctuidae) to Transgenic $B t$ Cotton (RCH 2) in South India. Biopestic. Int. 3, 71-78. 
Kranthi, S., Dhawad, S., Naidu, C.S., Bharose, A,. Chaudhary, A., Sangode, V., Nehare, S.K., Bajaj, S.R. and Kranthi, K.R. (2009). Susceptibility of the cotton boll-worm, Helicoverpa armigera (Hubner) (Lepidoptera: Noctuidae) to the Bacillus thuringiensis toxin Cry2 Ab before and after the introduction of Bollgard-II. Crop Prot. 28, 371-375.

Kranthi, K.R., Kranthi, S., Ali, S. and Banerjee, S.K. (2000). Resistance to Cry1Ac $\delta$ endotoxin of Bacillus thuringiensis in a laboratory selected strain of Helicoverpa armigera (Hubner). Curr. Sci. 78, 1001-1004.

Kranthi, K.R., Naidu, S., Dhawad, C.S., Tatwawadi, A., Mate, K., Patil, E., Bharose, A.A., Behere, G.T., Wadaskar, R.M. and Kranthi, S. (2005). Temporal and intra-plant variability of CrylAc expression in Bt cotton and its influence on the survival of the cotton bollworm, Helicoverpa armigera (Hübner) (Noctuidae: Lepidoptera). Curr. Sci. 89, 291-298.

Mohan, K.S. and Manjunath, T.M. (2002). Bt cotton - India's first transgenic crop. J. Plant Biol. 29, 225-236.

Naranjo, S.E. and Vicente, O. (2008). Transgenic plants for the third millennium agriculture. In: Paper Presented at $7^{\text {th }}$ International Symposium "Prospects for the 3rd Millennium Agriculture" - Sections Horticulture and Forestry; Economics and Management; Miscellaneous - Cluj-Napoca. Romania; 2-4 October 2008.

Navon, A. (2000). Bioassays of Bacillus thuringiensis products used against agricultural pests. In: Navon, A. and Acher, K.R.S. (Ed.) Bioassays of entomopathogenic microbes and nematodes. CABI publishing, UK. pp. 1-24.

Olsen, K.M., Daly, J.C. and Tanner, G.J. (1998). The effect of cotton condensed tannin on the efficacy of the CrylAc 6 - endotoxin of Bacillus thuringiensis. In: Proceedings, $9^{\text {th }}$ Australian Cotton Conference, 12-14 August 1998, Broadbeach, Queensland. Australian Cotton Growers Research Association, WeeWaa, NSW, Australia. pp. 337-342.

Olsen, K.M, Daly, J.L., Holt, H.E. and Finnegan, E.J. (2005). Seasonal long variation in expression of CrylAc gene and efficacy of Bacillus thuringiensis toxin in transgenic cotton against Helicoverpa armigera (Hubner) (Noctuidae: Lepidoptera). J. Econ. Entomol. 98, 1007-1017.

Patel, R.C., Patel, J.K., Patel, P.B. and Singh, R. (1968). Mass breeding of Heliothis armigera (H.). Indian J. Entomol. 30, 272-280.

Srinivasan, R. and Uthamasamy, S. (2006). Temporal variation in expression of toxicity in transgenic cottons against bollworm, Helicoverpa armigera (Lepidoptera: Noctuidae). Indian J. Agric.Sci. 76, 68-70.

Vitale, J., Glick, H., Greenplate, J., Abdennadher, M. and Traore, O. (2008). Secondgeneration Bt cotton field trials in Burkina Faso: analyzing the potential benefits to West African farmers. Crop Sci. 5, 1958-1966. 